\title{
Effect of the adenovirus-mediated Wip1 gene on lumbar intervertebral disc degeneration in a rabbit model
}

\author{
YUAN WANG ${ }^{*}$, YONG YANG ${ }^{*}$, JING-CHUAN SUN, QIN-JIE KONG, HAI-BO WANG and JIAN-GANG SHI \\ Department of Orthopedics, Shanghai Changzheng Hospital, Shanghai 200003, P.R. China
}

Received October 9, 2016; Accepted June 1, 2017

DOI: $10.3892 / \mathrm{mmr} .2017 .7774$

\begin{abstract}
The present study aimed to investigate the effect of the adenovirus-mediated wild-type $p 53$-induced protein phosphatase 1 (Wipl) gene on lumbar disc degeneration (LDD) in a rabbit model. Adult New Zealand white rabbits were used as experimental subjects. The rabbits were divided into LDD groups (groups A-C of rabbit models of LDD) and control groups (groups D-F of normal rabbits). The animals in groups $\mathrm{A}$ and $\mathrm{D}$ were injected with the Wipl gene vector, those in groups B and $\mathrm{E}$ were injected with an empty vector, and those in groups $\mathrm{C}$ and $\mathrm{F}$ were injected with phosphate-buffered saline. Type II collagen was detected using a streptavidin-biotin complex immunohistochemistry method. Postoperative X-ray imaging showed a significant increase in the recovery of rabbits from group A, compared with those from groups B and $\mathrm{C}$. The nucleus pulposus proteoglycan content of the intervertebral discs (L2-3, L3-4 and L4-5) of group A remained higher, compared with the content in groups $\mathrm{B}$ and $\mathrm{C}$, and the values in groups $\mathrm{B}$ and $\mathrm{C}$ differed from those of groups $\mathrm{E}$ and F. At 3, 6 and 9 weeks post-injection, the content of type II collagen of intervertebral discs (L2-3, L3-4 and L4-5) in group A differed from groups $\mathrm{B}$ and $\mathrm{C}$, and the values in groups A-C remained lower, compared with those in groups D-F. The Wipl gene exhibited a therapeutic effect in the treatment of LDD.
\end{abstract}

\section{Introduction}

Lumbar disk degeneration (LDD) results in bone instability, compression of neural elements and reduction of spinal canal dimensions, which seriously affect the quality of life

Correspondence to: Dr Jian-Gang Shi, Department of Orthopedics, Shanghai Changzheng Hospital, 415 Fengyang Road, Huangpu, Shanghai 200003, P.R. China

E-mail: gggbbbei@163.com

*Contributed equally

Key words: wild-type $p 53$-induced phosphatase gene, lumbar disc degeneration, clinical efficacy, transfection efficiency, expression intensity, core protein content, type II collagen content, multiplicity of infection of patients (1). LDD is generally caused by genetic, environmental, mechanical and other external factors $(2,3)$. At present, the treatment of LDD includes non-surgical treatment and surgical intervention, the purposes of which are to reduce pain (4). The surgical methods include the removal of intervertebral disc lesions and intervertebral disc arthroplasty, without addressing the inherent loss of disc functions (5). Fusion surgery has been identified as a viable treatment option for reducing chronic low back pain due to LDD for patients refractory to nonsurgical care (6). A previous study indicated that LDD may be affected by genetic factors, and that gene therapy may become the future direction of LDD treatment (7).

Wild-type $p 53$-induced protein phosphatase 1 (Wipl) is a serine/threonine protein phosphatase and a proto oncogene, which belongs to the protein phosphatase 2C family (8). Wipl, coded by phosphatase $\mathrm{Mg}^{2+}$-dependent $1 \delta$, is aberrantly amplified in different types of primary cancer in humans, and its deletion in mice has been found to result in a profound tumor-resistant phenotype (8). In the presence of $\mathrm{Mg}^{2+}$ and other divalent cations, Wipl is directly involved in the dephosphorylation and inactivation of proteins downstream of $p 53$, thereby inhibiting the DNA repair and apoptosis functions mediated by $p 53$ in damaged cells $(9,10)$. Adeno-associated virus (AAV) is a human virus with low immunogenicity, which can attach to human chromosomes precisely and steadily; therefore, AVV can be used as a stable and safe carrier for exogenous genes $(11,12)$. AAV vectors have been used in the treatment of several diseases and have become one of the most promising gene therapy vectors (13). The present aimed to examine the clinical efficacy of Wipl delivered by an AAV vector in targeted therapy for LDD.

\section{Materials and methods}

Ethical statement. The animal experiments were designed with the approval of the Animal Ethics Committee of Shanghai Changzheng Hospital (Shanghai, China) and all experiments were performed in accordance with the international standard (14).

Experimental subjects. A total of 84 healthy adult New Zealand white rabbits (Hubei Academy of Medical Sciences, Hubei, China) were selected for the experiments, regardless of gender. Their weights ranged between 2.5 and $3 \mathrm{~kg}$, and their ages ranged between 4 and 6 months. The rabbits were adaptively fed 
for 3 days prior to the experiments and were housed at $21-23^{\circ} \mathrm{C}$ and $60 \pm 5 \%$ humidity with a 12 -h light/dark cycle. During feeding, the rabbits received a rationed intake of food and water at regular intervals. The temperature, humidity and ventilation conditions were recorded to ensure the health of the rabbits.

Construction of Wipl gene vector. A recombinant adenovirus vector for Wipl (AdWipl) was constructed by the Transformation Research Laboratory of the Second Military Medical University (Shanghai, China), which included a green fluorescent protein (GFP) expression cassette. The recombinant adenovirus vector for GFP (AdGFP) expressed GFP only. The vectors were diluted with PBS to $5 \times 10^{5} \mathrm{pfu} / \mu 1$.

In vitro culture of intervertebral disc nucleus pulposus cells. A total of six rabbits were sacrificed prior to the removal of the lumbar spine, which was soaked in $75 \%$ of alcohol for $5 \mathrm{~min}$ and washed in $0.9 \%$ saline three times. The fiber rings in the intervertebral disc, between L1-L2 and L6-L7 were exposed under sterile conditions, revealing the nucleus pulposus tissues. The gel-like tissues were collected using metal tweezers and transferred into $5 \mathrm{ml}$ centrifuge tubes. The tissue samples were washed by centrifugation in Dulbecco's minimum essential medium (DMEM), at $200 \mathrm{xg}$ and $4^{\circ} \mathrm{C}$ for 5 min (model 800; SMEW, Shanghai, China). The samples were then digested in $0.25 \%$ type II collagenase (Invitrogen; Thermo Fisher Scientific, Inc., Waltham, MA, USA) for 20-25 min at $37^{\circ} \mathrm{C}$, vibrated for $5 \mathrm{~min}$ and washed again by centrifugation in DMEM three times at $200 \mathrm{x} \mathrm{g}$ and $4^{\circ} \mathrm{C}$ for 5 min. Finally, $1 \%$ of hyaluronic acid enzyme (Sigma; Merck Millipore, Darmstadt, Germany) was added to the samples and the cell numbers were counted in an automated cell counter (Vi-Cell XR; Beckman Coulter, Inc., Brea, CA, USA). The cells were then seeded at a density of $1.4 \times 10^{5}$ cells $/ \mathrm{ml}$ into 24-well culture plates, and cultured at $37^{\circ} \mathrm{C}$ with $5 \% \mathrm{CO}_{2}$ in DMEM containing $10 \%$ fetal bovine serum (FBS).

Determination of transfection efficiency. The culture solution was replaced every 3 days until the cells had completely fused; following which $0.25 \%$ trypsin was used to digest the cells for subculture. When the cells reached $80 \%$ confluence, the cells were removed from the culture medium. The recombinant adenovirus vector AdWipl was added to the cells at 25, 50, 100, 200, 400 and 800 multiplicity of infection (MOI), and incubated at $37^{\circ} \mathrm{C}$ with $5 \% \mathrm{CO}_{2}$. After $1 \mathrm{~h}$, the supernatant liquid was discarded, and fresh cell culture medium (DMEM+10\% FBS) was added into each well with $10 \mathrm{mM}$ sodium butyrate. The transfection efficiency was measured using flow cytometry.

Detection of cell growth and activity. The highest transfection efficiency and the optimal transfection concentration were detected using flow cytometry. The cells were divided into two groups: Recombinant vector Wipl group and blank control group. In the Wipl group, culture medium was removed and 200 MOI of Wipl vector was added into each well. The cells were incubated at $37^{\circ} \mathrm{C}$ with $5 \% \mathrm{CO}_{2}$ for $1 \mathrm{~h}$. The liquid supernatant was then discarded, and fresh DMEM containing $10 \%$ FBS medium was added with $10 \mathrm{mM}$ sodium butyrate. In the blank control group, the cells were cultured with DMEM+10\% FBS only. The growth of the cells was observed using a light microscope. At 1, 3, 5, 7, 9, 11 and 14 days post-transfection, the cells were counted and the cell growth curve was drawn.

Expression of AdWipl in nucleus pulposus tissues. A total of six rabbits were randomly selected for establishment of the animal model by annulus fibrosus of intervertebral disc injury (15). The rabbits were placed under anesthesia using an intravenous injection of $3 \%$ pentobarbital sodium, and the L2-3, L3-4 and L4-5 intervertebral disc regions were exposed by median incision of the abdomen and peritoneum. An injection needle (size 7) was used to puncture the annulus, following which the needle was withdrawn. If the puncture site leaked out some nucleus pulposus fluid, the surgery was complete. The intervertebral space was marked by suture marks on lumbar muscles. The incision was closed at the end of surgery. The normal diet and activities of the rabbits were maintained in the postoperative period. At 4 weeks following surgery, the AdWipl vectors were injected. At 1, 7, 14, 21 and 28 days post-injection, nucleus pulposus tissues in the lumbar intervertebral disc region were removed and pressed into slides. The fluorescence intensity of the tissues was observed using a fluorescence microscope, and the gene expression level of Wipl was analyzed using HPIAS 2000 image analysis software (Tongji Qianping Company, Wuhan, China). The pathological sections of the nucleus pulposus tissues were observed on the slides under an optical microscope.

Model establishment and grouping. A total of 72 rabbits were randomly divided into two primary groups, with each primary group further divided into three sub-groups. The first primary group included rabbits subjected to intervertebral disc injury by annulus fibrosus, and was further divided into groups A-C. The second primary group was the blank control group and was further divided into groups D-F. At 4 weeks following model establishment, the intervertebral disc (L2-3, L3-4 and L4-5) was exposed through left extra-peritoneal puncture. The AdWipl vectors were injected into the rabbits in groups A and D. Empty vectors were injected into the rabbits in groups B and $\mathrm{E}$. PBS was injected into the rabbits in groups $\mathrm{C}$ and $\mathrm{F}$.

X-ray examination of the lumbar spine. At 3, 6 and 9 weeks following the second surgical procedure, the rabbits in each group underwent X-ray examinations. The rabbits were maintained at the same depth of anesthesia during the examinations. A computed radiograph machine (Siemens AG, Munich, Germany) was used with the following scanning parameters: $50 \mathrm{kV}, 100 \mathrm{~mA}$ and $50 \mathrm{mS}$. Following acquisition of X-ray images, Centricity DICOM viewer 3.1.1 software (GEHealthcare Life Sciences, Little Chalfont, UK) was used to enlarge the images and measure the relevant parameters according to the referenced method (16). The anterior and posterior heights, and the intermediate heights of surgical segments L2-3, L3-4 and L4-5 were measured, and the average of these three values was calculated as the height of the intervertebral disc.

Determination of proteoglycan contents in the nucleus pulposus. A total of six rabbits in each group were randomly selected and sacrificed by ear venous air embolism. Their lumbar spines were removed and intervertebral discs (L2-3, L3-4 and L4-5) were separated. At each time point, the nucleus pulposus tissues from six intervertebral discs in each group 
were obtained. The tissues were placed in centrifuge tubes of $4 \mathrm{ml}$ in size. In each sample, $1 \mathrm{ml}$ of $3 \% \mathrm{NaOH}$ solution was added and incubated on an oscillator (Yunyan Instrument, Shanghai, China) at $40^{\circ} \mathrm{C}$ for $3 \mathrm{~h}$. Subsequently, $4 \mathrm{ml}$ of $\mathrm{HCl}$ was added into each sample to adjust the $\mathrm{pH}$ value to $8-9$, and $100 \mu \mathrm{l}$ of $100 \mathrm{mg} / \mathrm{ml}$ trypsin was added and incubated on the oscillator at $50^{\circ} \mathrm{C}$ for $2 \mathrm{~h}$. In the subsequent step, $30 \mathrm{ml}$ of glacial acetic acid, and $10 \mathrm{ml}$ of $50 \mathrm{mg} / \mathrm{ml}$ trihydroxybenzene and ethanol solution were mixed with $40 \mathrm{ml}$ of $\mathrm{HCl}$ to prepare the trihydroxybenzene solutions. Following enzymolysis, the samples were transferred into a $10 \mathrm{ml}$ volumetric flask and were diluted to the $10 \mathrm{ml}$ constant volume. Using a dropper, $1 \mathrm{ml}$ of the diluted sample solution was transferred into another $10 \mathrm{ml}$ volumetric flask, to which $3 \mathrm{ml}$ trihydroxybenzene solution was added and mixed. The mixture was heated in boiling water for $30 \mathrm{~min}$ prior to cooling in ice water for $5 \mathrm{~min}$. The mixture was then mixed with glacial acetic acid to the constant volume of $10 \mathrm{ml}$. Using the blank reagent alone as the reference; the optical densities (OD) of the samples were measured at a wavelength of $558 \mathrm{~nm}$, and were converted to the quantity of proteoglycan.

Detection of type II collagen via immunohistochemistry using streptavidin-biotin complex (SABC) method. The remaining six rabbits in each group were sacrificed following X-ray imaging by ear injection of air. The intervertebral discs (L2-3, L3-4 and L4-5) were separated from lumbar spine. At each time point, nine intervertebral disc specimens were continuously sectioned with a slicing machine (Leike, Hubei, China). The thickness of the sections was $4 \mu \mathrm{m}$. The slides were stained with 1:250 mouse anti-human collagen type II 1 (Col2a1) antibody (cat. no. sc-52658; 1:250; Santa Cruz Biotechnology, Inc., Dallas, TX, USA), and stored at $4^{\circ} \mathrm{C}$ overnight. The secondary antibody staining was performed using 1:1,000 biotinylated rabbit anti-mouse IgG (cat. no. ab6728; 1:1,000; Abcam, Cambridge, UK) and incubated at $37^{\circ} \mathrm{C}$ for $2 \mathrm{~h}$, and then developed using the SABC kit and DAB reagent (Boster Systems, Inc., Wuhan, China), in accordance with the manufacturer's protocol. The expression of Col2al was visualized using a marker index. In each slide, five high magnification visual fields were randomly selected, and the numbers of total cells and positive cells were counted under a fluorescence microscope (GVM-55; Shanghai Precision Instruments Co., Ltd., Shanghai, China). The percentage of positive cells was calculated and averaged for the five visual fields.

Statistical analysis. Statistical data analysis was performed using SPSS 19.0 statistical software (IBM SPPS, Armonk, NY, USA). The ranked data were confirmed using rank sum tests. The count data were compared using $\chi^{2}$ tests. The measurement data are presented as the mean \pm standard deviation and were verified using the Kolmogorov-Smirnov test of normality. The data between two groups were compared using an unpaired two-tailed Student's t-test. $\mathrm{P}<0.05$ was considered to indicate a statistically significant difference.

\section{Results}

Determination of the optimal concentration for Wipl gene vectors. The expression of Wipl was observed using a
Table I. Flow cytometry results

Virus concentration

(multiplicity of infection)

Positive cells (\%)

\begin{tabular}{rr}
25 & $21.32 \pm 2.71$ \\
50 & $45.56 \pm 2.91$ \\
100 & $66.11 \pm 1.06$ \\
200 & $89.65 \pm 2.47$ \\
400 & $80.41 \pm 3.32$ \\
800 & $74.19 \pm 3.11$ \\
\hline
\end{tabular}

fluorescence microscope as early as $12 \mathrm{~h}$ following transfection. The expression peaked $48 \mathrm{~h}$ post-transfection. The nucleus pulposus cells were transfected with six different virus concentrations $(25,50,100,200,400$ and $800 \mathrm{MOI})$ for $48 \mathrm{~h}$, and the results from the flow cytometry are shown in Table I. The results from the fluorescence microscopy showed that the transfection rate of the cells increased at higher concentrations of the virus, with $200 \mathrm{MOI}$ being the minimum dose required to reach the maximum rate of transfection (Fig. 1A-F).

Effect of the Wipl gene vector on the growth of nucleus pulposus cells. Following separation of the nucleus pulposus cells from the lumbar intervertebral disc, the numbers of living cells were counted using trypan blue staining. The results showed that the percentage of living cells was up to $93 \%$. The cells were seeded into 24 -well culture plates and cultured for 15 days, until the cells were fully fused and in good condition. The cell density increased from $1.37 \times 10^{5}$ to $3.68 \times 10^{5}$ cells $/ \mathrm{ml}$, and the percentage of living cells remained as high as $91 \%$. As shown in Fig. 2A and B, no significant differences were found between the virus infection group (200 MOI) and blank control group (0 MOI). As shown in Fig. 2C, within 14 days of 200 MOI AdWipl transfection, the cells continued to grow, and the rate of growth was almost identical with that of the blank control group.

Expression of AdWipl in rabbit nucleus pulposus tissues. At 7 days post-transfection of the Wipl gene vectors into the nucleus pulposus of rabbit intervertebral discs, the expression of Wipl was highest, followed by a gradual decrease. The OD values on days 7, 14, 21 and 28 were $0.0068 \pm 0.0031$, $0.0057 \pm 0.0028,0.0031 \pm 0.0011$ and $0.0013 \pm 0.0008$, respectively. Although the OD value on day 14 was marginally lower, compared with that on day 7 , the difference was not significant ( $P>0.05)$. However, the OD values on days 21 and 28 were decreased significantly $(\mathrm{P}<0.05)$, as shown in Fig. 3A-D.

General condition of the rabbits in each group. Following transfection, all rabbits were fed for $4-6 \mathrm{~h}$. At $24 \mathrm{~h}$ post-transfection, the rabbits resumed normal diets and activities. All rabbits had normal hair color, adequate reactions to external stimuli, and normal food intake and excrement. All wounds healed in phase I with no animal death. In groups A-C, the rabbits showed marginally slower activity following surgery, however, no significant differences were observed between the rabbits in groups D-F and the normal rabbits. With the passage of time, the activities of rabbits in group A gradually returned 
A

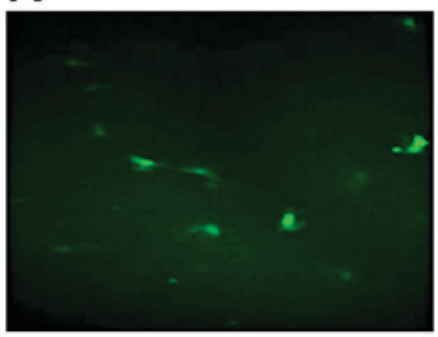

D

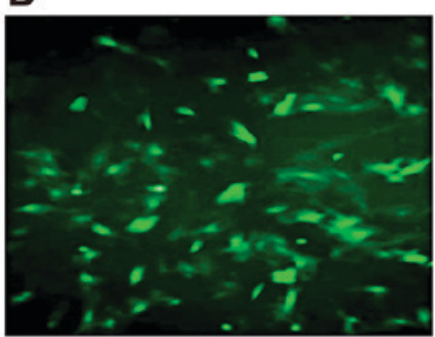

B

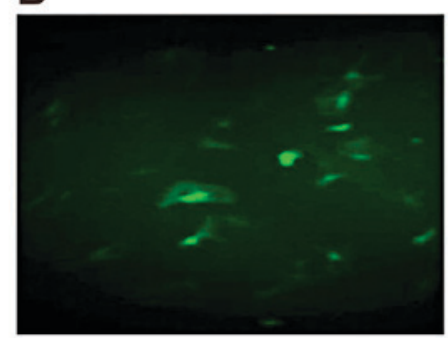

E

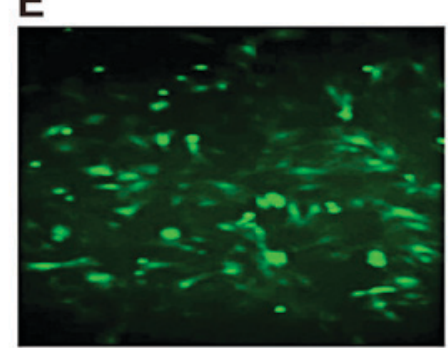

C

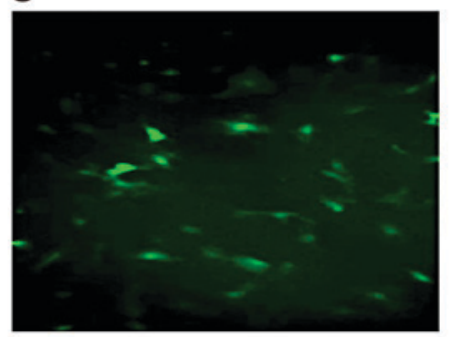

$\mathbf{F}$

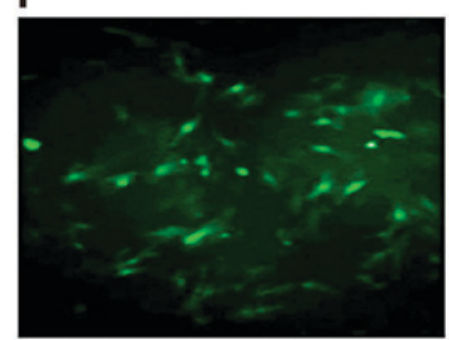

Figure 1. Transfection of nucleus pulposus cells by AdWipl at different viral concentrations. Images were captured under a fluorescence microscope (magnification, x100). (A) 25 MOI; (B) 50 MOI; (C) 100 MOI; (D) 200 MOI; (E) 400 MOI; (F) 800 MOI. Ad, adenovirus; Wip1, wild-type p53-induced protein phosphatase 1; MOI, multiplicity of infection.

A

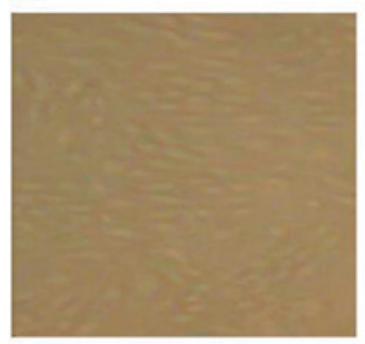

B

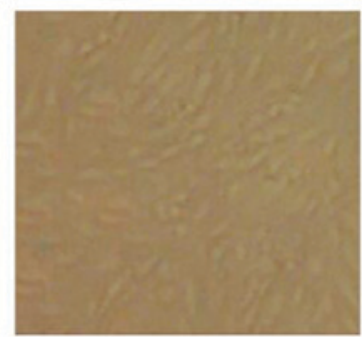

C

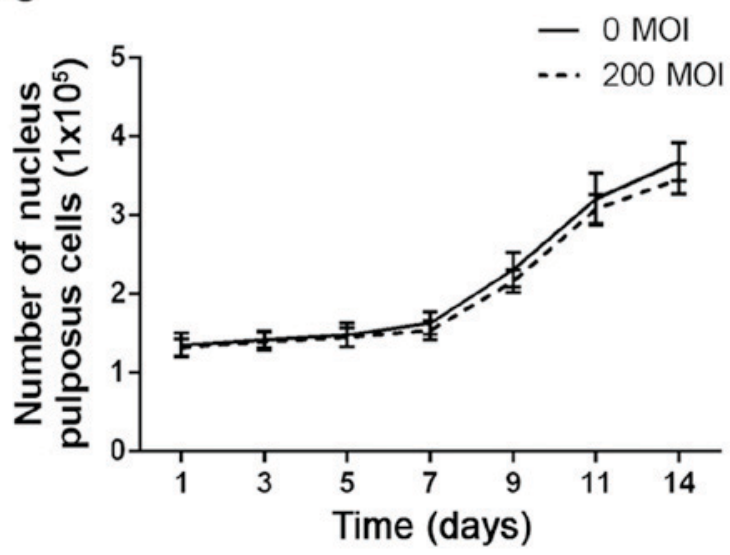

Figure 2. Numbers of nucleus pulposus cells. (A) Virus infection group and (B) blank control group (magnification, x100). (C) Growth curve of nucleus pulposus cells in the virus infection group (200 MOI) and blank control group (0 MOI). MOI, multiplicity of infection.

to a normal level, whereas the activities of rabbits in groups $\mathrm{B}$ and $\mathrm{C}$ were slower, and responses to external stimulation were lower than normal.

$X$-ray examination. Following surgery for model establishment, the lumbar spine was assessed using X-ray examination.
A

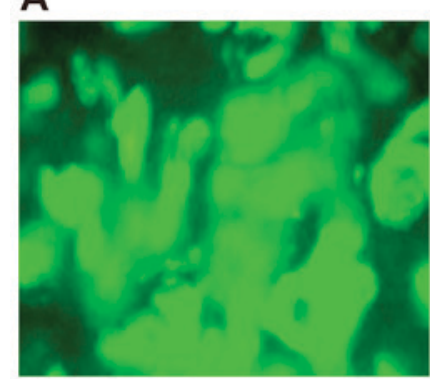

C

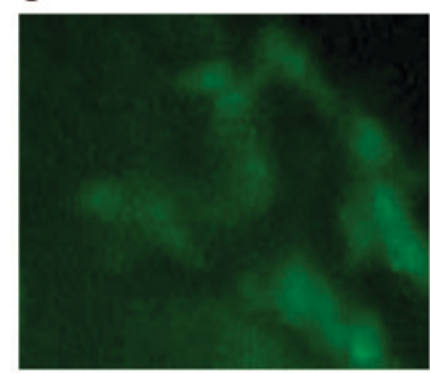

B

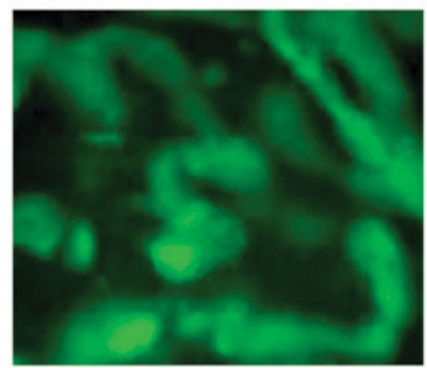

D

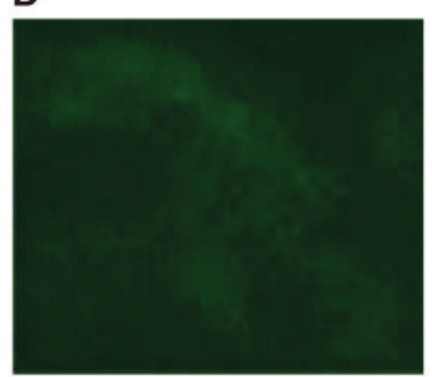

Figure 3. At different time points following AdWipl transfection, the nucleus pulposus tissues of the intervertebral disc were made into slides and observed under a fluorescence microscope (magnification, x200), (A) 7 days post-transfection; (B) 14 days post-transfection; (C) 21 days post-transfection; (D) 28 days post-transfection. Ad, adenovirus; Wipl, wild-type $p 53$-induced protein phosphatase 1 .

It was found that the intervertebral space was relatively normal, the bones of the upper and lower plates showed sclerosis, and the anterior vertebral bone showed osteoproliferation, as shown in Fig. 4A-C. At different time points, the heights of intervertebral disc spaces in groups $\mathrm{A}-\mathrm{C}$ differed from those in groups $\mathrm{D}-\mathrm{F}$ (all $\mathrm{P}<0.05)$. The values among groups $\mathrm{D}-\mathrm{F}$ were similar $(\mathrm{P}>0.05)$. At 3 weeks following surgery, no significant differences were found among groups $\mathrm{A}-\mathrm{C}$ (all $\mathrm{P}>0.05$ ). After 
Table II. X-ray results showing the height of intervertebral disc spaces at different time points.

\begin{tabular}{|c|c|c|c|c|}
\hline \multirow[b]{2}{*}{ Group } & \multirow[b]{2}{*}{ Sub-group } & \multicolumn{3}{|c|}{ Height of intervertebral disc space (mm) } \\
\hline & & 3 weeks & 6 weeks & 9 weeks \\
\hline \multirow[t]{3}{*}{ AdWipl } & A & $0.75 \pm 0.09$ & $0.63 \pm 0.08$ & $0.73 \pm 0.08$ \\
\hline & B & $0.61 \pm 0.08$ & $0.42 \pm 0.05$ & $0.56 \pm 0.05$ \\
\hline & $\mathrm{C}$ & $0.67 \pm 0.08$ & $0.46 \pm 0.06$ & $0.52 \pm 0.06$ \\
\hline \multirow[t]{3}{*}{ Control } & $\mathrm{D}$ & $0.91 \pm 0.10$ & $0.83 \pm 0.10$ & $0.90 \pm 0.08$ \\
\hline & E & $0.92 \pm 0.13$ & $0.89 \pm 0.09$ & $0.93 \pm 0.10$ \\
\hline & $\mathrm{F}$ & $0.97 \pm 0.12$ & $0.90 \pm 0.12$ & $0.94 \pm 0.11$ \\
\hline
\end{tabular}

Data are presented as the mean \pm standard deviation. AdWip1, adenovirus vector for wild-type $p 53$-induced protein phosphatase 1 .

A

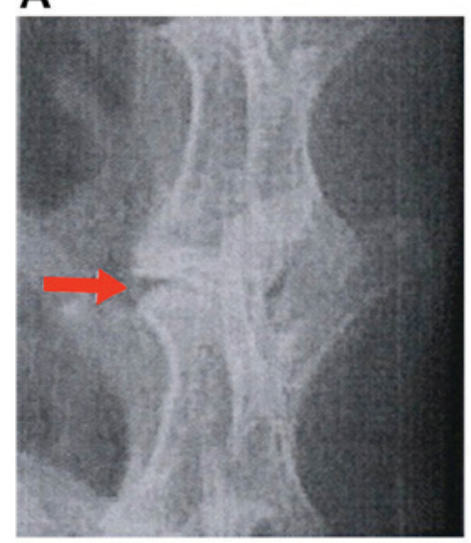

B

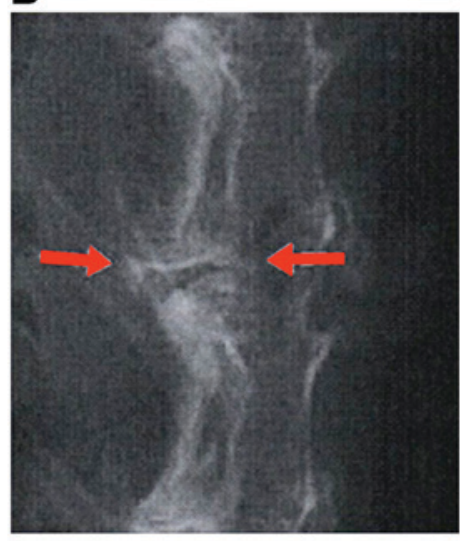

C

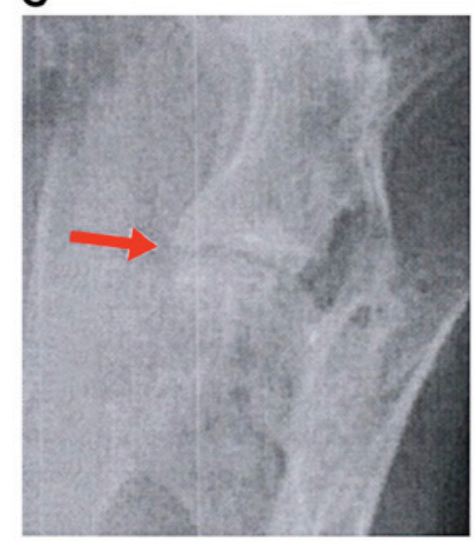

Figure 4. X-ray results of intervertebral space degeneration in the model group. The images present (A) a narrowing of the intervertebral space, (B) osteophyte formation and (C) alterations in the cartilage endplate. Red arrows indicate the intervertebral space following the establishment of the model.

6 and 9 weeks, the heights of the intervertebral disc spaces in group A were significantly different, compared with those in groups B and C (all $\mathrm{P}<0.05)$, as shown in Table II.

Determination of proteoglycan content in the nucleus pulposus. At 3, 6 and 9 weeks following the injection of AdWipl, the proteoglycan content in the nucleus pulposus of the intervertebral discs (L2-3, L3-4 and L4-5) were measured. The content of proteocylcan in group A remained higher, compared with the content in groups $\mathrm{B}$ and $\mathrm{C}(\mathrm{P}<0.05)$. The content among groups D-F was similar $(\mathrm{P}>0.05)$. The results in group $\mathrm{A}$ were similar to those in groups $\mathrm{D}-\mathrm{F}$ (all $\mathrm{P}>0.05$ ). However, the results in groups $\mathrm{B}$ and $\mathrm{C}$ differed from those in groups $\mathrm{E}$ and $\mathrm{F}$ (all $\mathrm{P}<0.05$; Table III).

Type II collagen. At 3, 6 and 9 weeks following the injection of AdWipl, the levels of type II collagen were measured in the nucleus pulposus of the intervertebral discs (L2-3, L3-4 and L4-5). The results are shown in Table IV. The content of type II collagen differed in group A, compared with the content in groups $\mathrm{B}$ and $\mathrm{C}(\mathrm{P}<0.05)$. The results from groups $\mathrm{B}$ and $\mathrm{C}$ were similar $(\mathrm{P}>0.05)$. The results among groups $\mathrm{D}-\mathrm{F}$ were similar $(\mathrm{P}>0.05)$. The type II collagen contents in groups A-C were lower compared with those in groups $\mathrm{D}-\mathrm{F}($ all $\mathrm{P}<0.05)$.

\section{Discussion}

LDD is primarily manifested as bone hyperplasia, end plate sclerosis and intervertebral disc space narrowing, resulting in back pain (17). Currently, surgery and non-surgical treatments are used in parallel to alleviate pain, however, it is difficult to always achieve satisfactory results. In addition, there is a risk associated with LDD surgery, which may worsen the degeneration of adjacent tissues (18). As current understanding the cause of LDD at the genetic level has improved, innovative treatment strategies may become available for LDD.

The experimental results in the present study showed that the transfection of AdWipl into New Zealand white rabbits caused significant recovery from LDD, but could not completely eliminate the disease. Intervertebral discs contain three major components: A gel-like nucleus pulposus to resist internal pressure, fiber rings to resist external pressure, and cartilage end plates (19). It has been shown that LDD is closely associated with reduced height of the intervertebral disc (20). During the degeneration of lumbar intervertebral discs, modic changes generally occur in patients, including degeneration, damage to cartilage endplates in the regeneration and vascular granulation regions, fractures, and increased signal intensity in bone tissues and granulation tissues (21). These external stimuli can trigger the DNA damage response (DDR) in cells, which 
Table III. Proteoglycan content in nucleus pulposus cells of the intervertebral discs in each group.

\begin{tabular}{|c|c|c|c|c|}
\hline Group & Weeks post-injection & L2-3 (mg/g) & L3-4 (mg/g) & $\mathrm{L} 4-5(\mathrm{mg} / \mathrm{g})$ \\
\hline \multirow[t]{3}{*}{ A } & 3 & $5.06 \pm 0.31$ & $5.19 \pm 0.22$ & $5.13 \pm 0.19$ \\
\hline & 6 & $4.99 \pm 0.28$ & $5.07 \pm 0.18$ & $5.09 \pm 0.16$ \\
\hline & 9 & $4.84 \pm 0.31$ & $4.91 \pm 0.21$ & $5.03 \pm 0.22$ \\
\hline \multirow[t]{3}{*}{ B } & 3 & $4.62 \pm 0.17$ & $4.78 \pm 0.12$ & $4.68 \pm 0.14$ \\
\hline & 6 & $4.58 \pm 0.18$ & $4.65 \pm 0.20$ & $4.59 \pm 0.12$ \\
\hline & 9 & $4.49 \pm 0.11$ & $4.38 \pm 0.17$ & $4.45 \pm 0.11$ \\
\hline \multirow[t]{3}{*}{$\mathrm{C}$} & 3 & $4.58 \pm 0.28$ & $4.69 \pm 0.16$ & $4.62 \pm 0.15$ \\
\hline & 6 & $4.45 \pm 0.21$ & $4.58 \pm 0.19$ & $4.49 \pm 0.14$ \\
\hline & 9 & $4.42 \pm 0.17$ & $4.49 \pm 0.21$ & $4.40 \pm 0.13$ \\
\hline \multirow[t]{3}{*}{$\mathrm{D}$} & 3 & $4.88 \pm 0.25$ & $4.92 \pm 0.26$ & $4.86 \pm 0.25$ \\
\hline & 6 & $4.76 \pm 0.31$ & $4.81 \pm 0.29$ & $4.72 \pm 0.26$ \\
\hline & 9 & $4.68 \pm 0.21$ & $4.74 \pm 0.31$ & $4.63 \pm 0.26$ \\
\hline \multirow[t]{3}{*}{$\mathrm{E}$} & 3 & $5.10 \pm 0.24$ & $5.21 \pm 0.32$ & $5.18 \pm 0.28$ \\
\hline & 6 & $5.01 \pm 0.29$ & $5.09 \pm 0.28$ & $5.06 \pm 0.31$ \\
\hline & 9 & $4.92 \pm 0.24$ & $4.98 \pm 0.31$ & $4.97 \pm 0.33$ \\
\hline \multirow[t]{3}{*}{$\mathrm{F}$} & 3 & $5.17 \pm 0.26$ & $5.23 \pm 0.32$ & $5.22 \pm 0.30$ \\
\hline & 6 & $5.06 \pm 0.23$ & $5.11 \pm 0.26$ & $5.10 \pm 0.33$ \\
\hline & 9 & $4.98 \pm 0.32$ & $5.04 \pm 0.24$ & $5.03 \pm 0.29$ \\
\hline
\end{tabular}

Table IV. Type II collagen content in nucleus pulposus cells of intervertebral discs in each group.

\begin{tabular}{|c|c|c|c|c|}
\hline Group & Weeks post-injection & $\mathrm{L} 2-3(\mathrm{mg} / \mathrm{g})$ & $\mathrm{L} 3-4(\mathrm{mg} / \mathrm{g})$ & $\mathrm{L} 4-5(\mathrm{mg} / \mathrm{g})$ \\
\hline \multirow[t]{3}{*}{ A } & 3 & $119.56 \pm 4.62$ & $121.25 \pm 4.37$ & $123.33 \pm 5.69$ \\
\hline & 6 & $112.33 \pm 5.15$ & $120.24 \pm 5.63$ & $120.66 \pm 4.44$ \\
\hline & 9 & $104.43 \pm 4.18$ & $105.76 \pm 4.38$ & $106.75 \pm 4.48$ \\
\hline \multirow[t]{3}{*}{ B } & 3 & $87.33 \pm 4.26$ & $84.75 \pm 3.77$ & $84.42 \pm 3.23$ \\
\hline & 6 & $85.41 \pm 3.93$ & $83.59 \pm 3.74$ & $80.12 \pm 3.03$ \\
\hline & 9 & $79.56 \pm 3.02$ & $82.35 \pm 3.21$ & $78.52 \pm 3.16$ \\
\hline \multirow[t]{3}{*}{$\mathrm{C}$} & 3 & $86.81 \pm 3.95$ & $85.77 \pm 4.11$ & $85.52 \pm 4.12$ \\
\hline & 6 & $84.38 \pm 3.86$ & $83.58 \pm 3.81$ & $84.87 \pm 3.97$ \\
\hline & 9 & $79.67 \pm 2.99$ & $82.86 \pm 3.05$ & $81.58 \pm 3.14$ \\
\hline \multirow[t]{3}{*}{$\mathrm{D}$} & 3 & $140.13 \pm 6.34$ & $141.36 \pm 6.35$ & $140.37 \pm 6.42$ \\
\hline & 6 & $137.43 \pm 5.63$ & $139.74 \pm 5.28$ & $138.49 \pm 6.54$ \\
\hline & 9 & $136.58 \pm 6.15$ & $137.45 \pm 6.36$ & $136.32 \pm 5.85$ \\
\hline \multirow[t]{3}{*}{$\mathrm{E}$} & 3 & $138.43 \pm 6.14$ & $140.31 \pm 5.42$ & $140.34 \pm 6.15$ \\
\hline & 6 & $136.15 \pm 6.32$ & $138.21 \pm 6.54$ & $137.69 \pm 5.81$ \\
\hline & 9 & $134.36 \pm 5.82$ & $134.14 \pm 6.32$ & $134.43 \pm 6.94$ \\
\hline \multirow[t]{3}{*}{$\mathrm{F}$} & 3 & $141.51 \pm 5.64$ & $142.36 \pm 6.58$ & $141.11 \pm 6.84$ \\
\hline & 6 & $138.37 \pm 6.21$ & $141.22 \pm 6.28$ & $139.54 \pm 5.76$ \\
\hline & 9 & $137.46 \pm 6.36$ & $138.62 \pm 6.83$ & $137.44 \pm 6.42$ \\
\hline
\end{tabular}

Data are presented as the mean \pm standard deviation.

has a dual effect: It prevents the propagation of DNA damage intracellularly, as DDR inhibits DNA replication and promotes the decomposition of damaged DNA; however, DDR tends to coordinate the internal repair of DNA in order to maintain the integrity of the genome (22). Therefore, in addition to the DDR repairing damage, it can also lead to the aging of intervertebral disc cells by inhibiting DNA replication. Wipl is an important molecule, which inhibits the activity of DDR-associated molecules through dephosphorylation, causing the timely termination of DDR (23-25). The experimental results of the 
present study showed that the intervertebral disc height in the groups transfected with AdWipl increased, indicating that the expression of Wipl improved the prognosis of LDD.

The results of the present study also showed that the type II collagen and proteoglycan contents were increased in the groups transfected with AdWipl. The extracellular matrix of the intervertebral disc primarily contains collagen (predominantly type II collagen), proteoglycan, elastin and water. In each layer of the fiber rings, grids are formed by elastin and collagen fitting closely, and proteoglycan is integrated into these grids (26). It has also been shown that the aging of nucleus pulposus cells is the primary cause of intervertebral disc degeneration (27). Following the occurrence of disc degeneration, the separation lines between the fiber rings and nucleus pulposus becomes less clear, the ability of the nucleus pulposus to synthesize proteins and sugar is decreased, the arrangements and types of collagen are altered, and the corresponding biological functions of the nucleus pulposus is significantly weakened (28). It has been shown that the expression of Wipl prevented the premature senescence of cells (29). Therefore, transfection of the Wipl gene into cells may inhibit the senescence of nucleus pulposus cells, and the increased levels of proteoglycan and type II collagen contents may assist in the treatment of LDD.

In conclusion, Wipl gene vectors showed promising clinical efficacy for the treatment of LDD in the present study. The optimum concentration of Wipl gene vectors was 200 MOI. The AAV delivery of the Wipl gene may become a novel targeted approach to treat LDD. However, the sample size in the present study was limited, therefore, the clinical significance of the results requires further verification in future experiments with larger sample sizes.

\section{Acknowledgements}

This study was supported in part by the National Natural Science Foundation of China (grant no. 8127135).

\section{References}

1. Lee SY, Kim TH, Oh JK, Lee SJ and Park MS: Lumbar stenosis: A recent update by review of literature. Asian Spine J 9: 818-828, 2015.

2. Tian W and Qi H: Association between intervertebral disc degeneration and disturbances of blood supply to the vertebrae. Chin Med J (Engl) 123: 239-243, 2010.

3. Eskola PJ, Lemmelä S, Kjaer P, Solovieva S, Männikkö M, Tommerup N, Lind-Thomsen A, Husgafvel-Pursiainen K, Cheung KM, Chan D, et al: Genetic association studies in lumbar disc degeneration: A systematic review. PLoS One 7: e49995, 2012.

4. Natarajan RN and Andersson GB: Lumbar disc degeneration is an equally important risk factor as lumbar fusion for causing adjacent segment disc disease. J Orthop Res 35: 123-130, 2017.

5. Tschugg A, Michnacs F, Strowitzki M, Meisel HJ and Thomé C: A prospective multicenter phase I/II clinical trial to evaluate safety and efficacy of NOVOCART Disc plus autologous disc chondrocyte transplantation in the treatment of nucleotomized and degenerative lumbar disc to avoid secondary disease: Study protocol for a randomized controlled trial. Trials 17: 108, 2016.

6. Phillips FM, Slosar PJ, Youssef JA, Andersson G and Papatheofanis F: Lumbar spine fusion for chronic low back pain due to degenerative disc disease: A systematic review. Spine (Phila Pa 1976) 38: E409-E422, 2013.

7. Woods BI, Vo N, Sowa G and Kang JD: Gene therapy for intervertebral disk degeneration. Orthop Clin North Am 42: 563-574, 2011.
8. Le Guezennec X and Bulavin DV: WIP1 phosphatase at the crossroads of cancer and aging. Trends Biochem Sci 35: 109-114, 2010.

9. Pechackova S, Burdova K, Benada J, Kleiblova P, Jenikova G and Macurek L: Inhibition of WIP1 phosphatase sensitizes breast cancer cells to genotoxic stress and to MDM2 antagonist nutlin-3. Oncotarget 7: 14458-14475, 2016.

10. Clausse V, Goloudina AR, Uyanik B, Kochetkova EY, Richaud S, Fedorova OA, Hammann A, Bardou M, Barlev NA, Garrido C and Demidov ON: Wee1 inhibition potentiates Wip1-dependent p53-negative tumor cell death during chemotherapy. Cell Death Dis 7: e2195, 2016.

11. Wang L, Wang Z, Zhang F, Zhu R, Bi J, Wu J, Zhang H, Wu H, Kong W, Yu B and Yu X: Enhancing transgene expression from recombinant AAV8 vectors in different tissues using woodchuck hepatitis virus post-transcriptional regulatory element. Int J Med Sci 13: 286-291, 2016.

12. Ling C, Yin Z, Li J, Zhang D, Aslanidi G and Srivastava A: Strategies to generate high-titer, high-potency recombinant AAV3 serotype vectors. Mol Ther Methods Clin Dev 3: 16029, 2016.

13. Nicolson SC, Li C, Hirsch ML, Setola V and Samulski RJ: Identification and validation of small molecules that enhance recombinant Adeno-associated virus transduction following high throughput screen. J Virol 90: 7019-7031, 2016.

14. Orlans FB: Ethical decision making about animal experiments. Ethics Behav 7: 163-171, 1997.

15. Paul R, Haydon RC, Cheng H, Ishikawa A, Nenadovich N, Jiang W, Zhou L, Breyer B, Feng T, Gupta P, et al: Potential use of Sox 9 gene therapy for intervertebral degenerative disc disease. Spine (Phila Pa 1976) 28: 755-763, 2003.

16. Kim KS, Yoon ST, Li J, Park JS and Hutton WC: Disc degeneration in the rabbit: A biochemical and radiological comparison between four disc injury models. Spine (Phila Pa 1976) 30: 33-37, 2005.

17. de Schepper EI, Damen J, van Meurs JB, Ginai AZ, Popham M, Hofman A, Koes BW and Bierma-Zeinstra SM: The association between lumbar disc degeneration and low back pain: The influence of age, gender, and individual radiographic features. Spine (Phila Pa 1976) 35: 531-536, 2010.

18. Liu Y, Yu T, Ma XX, Xiang HF, Hu YG and Chen BH: Lentivirusmediated TGF- $\beta 3$, CTGF and TIMP1 gene transduction as a gene therapy for intervertebral disc degeneration in an in vivo rabbit model. Exp Ther Med 11: 1399-1404, 2016.

19. Choi YS: Pathophysiology of degenerative disc disease. Asian Spine J 3: 39-44, 2009.

20. Ryu R, Techy F, Varadarajan R and Amirouche F: Effect of interbody fusion on the remaining discs of the lumbar spine in subjects with disc degeneration. Orthop Surg 8: 27-33, 2016.

21. Albert HB and Manniche C: Modic changes following lumbar disc herniation. Eur Spine J 16: 977-982, 2007.

22. d'Adda di Fagagna F: Living on a break: Cellular senescence as a DNA-damage response. Nat Rev Cancer 8: 512-522, 2008.

23. Hat B, Kochańczyk M, Bogdał MN and Lipniacki T: Feedbacks, bifurcations, and cell fate decision-making in the p53 system. PLoS Comput Biol 12: e1004787, 2016.

24. Mirzayans R, Andrais B, Scott A, Wang YW, Weiss RH and Murray D: Spontaneous $\gamma \mathrm{H} 2 \mathrm{AX}$ foci in human solid tumor-derived cell lines in relation to p21WAF1 and WIP1 expression. Int J Mol Sci 16: 11609-11628, 2015.

25. Iwamoto K, Hamada H, Eguchi Y and Okamoto M: Stochasticity of intranuclear biochemical reaction processes controls the final decision of cell fate associated with DNA damage. PLoS One 9: e101333, 2014.

26. Le Maitre CL, Pockert A,Buttle DJ, Freemont AJ and Hoyland JA: Matrix synthesis and degradation in human intervertebral disc degeneration. Biochem Soc Trans 35: 652-655, 2007.

27. Tang X, Jing L, Richardson WJ, Isaacs RE, Fitch RD, Brown CR, Erickson MM, Setton LA and Chen J: Identifying molecular phenotype of nucleus pulposus cells in human intervertebral disc with aging and degeneration. J Orthop Res 34: 1316-1326, 2016.

28. Le Maitre CL, Freemont AJ and Hoyland JA: Accelerated cellular senescence in degenerate intervertebral discs: A possible role in the pathogenesis of intervertebral disc degeneration. Arthritis Res Ther 9: R45, 2007.

29. Sakai H, Fujigaki H, Mazur SJ and Appella E: Wild-type p53-induced phosphatase 1 (Wip1) forestalls cellular premature senescence at physiological oxygen levels by regulating DNA damage response signaling during DNA replication. Cell Cycle 13: 1015-1029, 2014. 